\title{
A Study of the Economic and Non-Financial Performance Indicators in Corporate Sustainability Reports
}

\author{
Domenico Raucci ${ }^{1} \&$ Lara Tarquinio $^{1}$ \\ ${ }^{1}$ Department of Economic Studies, G. d'Annunzio University, Pescara, Italy \\ Correspondence: Domenico Raucci, Department of Economic Studies, G. d'Annunzio University, Pescara, Italy. \\ Tel: 39-085-453-7945. E-mail: d.raucci@unich.it
}

Received: May 28, 2015 Accepted: June 12, 2015 Online Published: July 29, 2015

doi:10.5539/jsd.v8n6p216 URL: http://dx.doi.org/10.5539/jsd.v8n6p216

\begin{abstract}
The purpose of this paper is to identify the performance indicators disclosed in corporate sustainability reports. To perform this study we examined Italian Listed companies that produced a sustainability report in 2012 . The indicators were identified using a content analysis. We analysed the core and additional indicators disclosed in sustainability reports as well as all the indicators required by sector supplements adopted by companies. Our results show that indicators are widely disclosed in Italian sustainability reports. Social indicators are on average the most commonly used indicators, particularly those concerning labour practices, followed by the economic and then the environmental indicators. The Oil and Gas and Utilities industry sectors disclosed a superior amount of indicators compared to all other sectors. These industry sectors also show a more homogeneous behaviour, also as regards disclosure of core and additional indicators.
\end{abstract}

This study provides one of the first detailed analyses of the different category of GRI indicators used by Italian companies producing sustainability reports.

Keywords: economic indicators, non-financial indicators, sustainability reports

\section{Introduction}

The growing use of Corporate Social Responsibility (CSR) reporting in recent years has generated the spread of guidelines and standards for use in the drafting of such reports (e.g. AccountAbility 1000 Accountability Principles Standard [AA1000 APS], 2008; Gruppo di Studio per il Bilancio Sociale [GBS], 2013; Global Reporting Initiative [GRI] $1.0 ; 2.0 ; 3.0 ; 3.1 ; 4.0)$. Among these, the guidelines proposed by the Global Reporting Initiative (GRI) are those most commonly used worldwide (KPMG, 2008, 2011; 2013; CorporateRegister.com, 2013). In fact, despite considerable criticism of the GRI model (Brown, de Jong, \& Levy, 2009; Milne \& Gray, 2013; Gray \& Milne, 2002; Moneva, Archel, \& Correa, 2006; Boiral, 2013), the GRI guidelines support the production of balanced and reliable sustainability reporting for the benefit of stakeholders.

One of the most distinguishing features of the GRI Guidelines, even in its earliest version $(\mathrm{G} 1,2000)$, is the inclusion of a set of indicators designed to represent a company's economic, social, and environmental performance. Many things have changed between the first version of the GRI guidelines and the fourth version, such as the number of environmental, social and economic indicators, as well as the conceptualization of these indicators and the consideration of integrated indicators. Initially the indicators were defined according to aspects considered material (core) by the company and its stakeholders, or representing an emerging practice or one of particular interest to certain organizations (additional).

Since G2, the presentation of the indicators in sustainability reports has been supported by the existence of Indicator Protocols. The 2002 GRI family of documents began gradually including Sector Supplements (SS) proposed generally in the form of performance indicators and their associated indicator protocols. The SS provide interpretations and guidance on how to apply the GRI Guidelines in a given sector and they include sector-specific Performance Indicators. With the adoption of G3 (GRI, 2006) and again with G3.1 (GRI, 2001), the number and type of indicators to be presented in the sustainability report varied depending on the GRI Application Levels. The maximum application level "A +", provides the inclusion of the core indicators of G3 and G3.1 in the report, as well as each performance indicator of the Sector Supplement in accordance with the materiality principle and requires an explanation if these are omitted. For each of the application levels, a "+" 
sign can be added when a reporting organization has had its reporting externally assured. The lowest level of application "C" provides the reporting of at least 10 indicators, including at least one from each of the three dimensions (social, economic, and environment). Moreover, GRI G3.1 states that the performance indicators may be selected from any finalized sector supplement, but 7 of the 10 must be from the original GRI Guidelines.

Performance indicators are synthetic, relevant, and comparable measurements that can be applied to companies of all sizes and from any sector or country. They are useful in decision-making processes and in the management of a company's socio-environmental issues (Olsthoorn, Tyteca, Wagner, \& Wehrmeyer, 2001; Jasch, 2000; 2009; Daub, 2007; Adams \& Frost, 2008; Mio, 2010).

Despite this, however, few studies have specifically analysed the performance indicators used by companies in their CSR reports.

Many papers have only focused on the study of individual categories of indicators, often of an environmental nature (Azzone \& Dubini, 1993; Ilinitch, Soderstrom, \& Thomas, 1998; Jasch, 2000, 2009; Olsthoorn et al., 2001; Gallego-Àlvarez, 2012). Other studies have examined indicators as part of a wider review of the full contents of the responsibility reports to analyse not only their "quality", but also the level of compliance to GRI Guidelines and/or environmental standards (Morhardt, Baird, \& Freeman, 2002; Guthrie \& Farneti, 2008; Skouloudis \& Evangelinos, 2009; Skouloudis, Evangelinos, \& Kourmousis, 2010; Asif, Searcy, dos Santos, \& Kensah, 2013; Legendre \& Coderre, 2013; Romolini, Fissi, \& Gori, 2014).

Very few studies have focused specifically on the ways in which companies include economic, environmental, and social indicators in their GRI-based sustainability reports (Gallego, 2006; Roca \& Searcy, 2012; Samuel, Agamuthu, \& Hashim, 2013; Alazzani \& Wan-Hussin, 2013). Indeed, we chose to investigate this issue in the present work due to the dearth of studies with this specific perspective.

In particular, our objective is to verify the number and type of economic, environmental, and social indicators present in the sustainability reports produced by the companies listed on the Italian Stock Exchange that produce CSR reports in accordance with the GRI Guidelines. The decision to investigate the Italian case was determined by the dissemination of responsibility reporting here (KPMG, 2008; 2011;2013) and the high quality of CSR reports by Italian companies, as demonstrated by the results of the last KPMG survey in 2013. Indeed, Italian companies stood out among the larger European companies and were followed by companies in Spain and the UK.

To achieve our objective, the paper has been structured as follows: the next section contains a brief review of the literature on GRI indicators in sustainability reports and is followed by an empirical analysis that introduces the research sample and methodology; lastly, we will share our results and offer our conclusions.

\subsection{Performance Indicators and GRI-based Sustainability Reports}

As stated earlier, the indicators are useful tools for analysis and control of business performance and can express the complex and dynamic events that characterize enterprise management in a synthetic and integrated way (Schaltegger \& Burritt, 2000; Adams \& Frost, 2008). These measurements are useful in decision-making processes and in the management of a company's socio-environmental issues and they make it possible to:

- identify and achieve social, environmental and economic objectives by controlling the degree of achievement and value over time;

- identify areas of inefficiecy;

- pursue benchmarking purposes (Jasch, 2009; Schaltegger \& Burrit, 2000; Mio, 2001; 2005; Perrini \& Tencati, 2006).

Furthermore, indicators are useful tools in external communication; through indicators stakeholders can evaluate a company's commitment and results, as well as make inter-temporal and intrasectoral comparisons. Wilburn and Wilburn (2013, p. 73) state that performance indicators offer stakeholders «[...] a means to evaluate the ethical basis of a company's CSR/sustainability programs».

Despite their informational value, however, few studies have specifically analysed the performance indicators used by companies in their CSR reports.

As previously mentioned, one of the most distinguishing features of the GRI Guidelines, even in its earliest version (G1, 2000), is the inclusion of a set of indicators designed to represent a company's economic, social, and environmental performance. After the year 2000, the GRI published three other versions of the GRI guidelines. The G2 were published in 2002 and replaced by the G3 in 2006, which were then partially revised by G3.1 in 2011. The G4, approved in 2013, is the most recent version of the GRI guidelines. 
All these versions of the guidelines classify sustainability indicators from the perspective of the Triple Bottom Line (Elkington, 1997), distinguishing between economic, environmental and social indicators. GRI indicators are classified into "aspects", while the social indicators alone (with partial differences for G1) are divided into "categories" relating to labour practices, human rights, society and product responsibility.

The various revisions of the GRI guidelines have always served to enhance the indicators, thus confirming their importance.

In the transition from the first version of the guidelines to the G2, the most significant changes affected the economic and social indicators. Moreover, the distinction between "core" and "additional" indicators was introduced with G2. Specifically, the "core" indicators are considered important for both users and reporters and for most organizations, while the "additional" indicators «[...] are those that have one or more of the following characteristics: represent a leading practice in economic, environmental, or social measurement, though currently used by few reporting organisations; provide information of interest to stakeholders who are particularly important to the reporting entity; and are deemed worthy of further testing for possible consideration as future core indicators» $(\mathrm{G} 2,2002$, p.13).

The G3 considerably altered the division of sustainability indicators into categories and aspects by proposing a more structured and synthetic framework of indicators. These guidelines were then modified in G3.1, with significant changes to the social indicators. Specifically, more relevance was given to the impact of the company on the local community, human rights and gender.

The G4, the fourth generation of GRI guidelines, also changed the indicators, especially the environmental and social ones (in particular for the categories relating to labour practices, human rights and society), and integrated information on the supply chain.

Furthermore, G4 deleted the distinction between core and additional indicators. All indicators, in each aspect, are considered «[...] as equal inputs in the process for defining report content» $(\mathrm{G} 4,2014$, p. 20$)$.

In addition to the GRI indicators, the different versions of the guidelines also provide that companies can use other sector-specific performance indicators, included in the Sector Supplements, (G2; 3; 3.1; 4) (Note 1) or, as specified in the G4, indicators relating to "material topics" and not included in the list of GRI indicators (G4, 2014; GRI, 2014).

Based on these observations, the next section provides a brief review of the literature of responsibility accounting and reporting and the contribution of these studies regarding the different use of GRI indicators.

\subsection{Background and Prior Studies}

We have already seen that the current literature on responsibility accounting and reporting has provided a limited or marginal analysis of one of the most significant components of the sustainability report, i.e. the indicators of economic, environmental and social performance.

Many studies analysed only one particular type of indicator: environmental, social or economic (Azzone \& Dubini, 1993; Ilinitch et al., 2008; Jasch, 2000; Olsthoorn et al., 2001; Gallego-Àlvarez, 2012). Olsthoorn et al. (2001, p. 456) point out that the study of environmental indicators especially, although relatively "new", «[...] is already highly diversified with approaches based on LCA, economics, management accounting, ecology and a physical gate-to-gate analysis». Other studies have extended the analysis to the three types of GRI indicators, but analyse them within the scope of broader research covering the full content of responsibility reports, as well as the "quality" and level of compliance to GRI Guidelines and/or environmental standards (Morhardt et al., 2002; Guthrie \& Farneti, 2008; Skouloudis \& Evangelinos, 2009; Skouloudis et al., 2010; Asif et al., 2013; Romolini et al., 2014).

Yet few studies have specifically examined the use of GRI indicators in companies' sustainability reports (Gallego, 2006; Roca \& Searcy, 2012; Samuel et al., 2013; Alazzani \& Wan-Hussin, 2013).

Gallego (2006) analyses the disclosure of GRI indicators (2002 version) in the sustainability reports of 19 Spanish companies. The results reveal attention to social issues, primarily in terms of indicators related to labour, practices and decent work, strategy and management, non-discrimination, freedom of association, child labour and forced and compulsory labour as well as environmental issues, primarily in terms of indicators related to energy, water, biodiversity and emissions, effluents and waste. Furthermore, the analysis shows that the sector of activity influences the type and the number of indicators disclosed.

Roca and Searcy (2012) provide a review of the indicators used in corporate sustainability reports. A content analysis of the reports published by 94 Canadian companies, divided into 10 sectors, revealed the use of 585 
different indicators, as well as the use of the indicators provided by the GRI G3 guidelines by 31 companies. While companies operating in the banking, engineering, construction and chemical production, mining, transportation, communications and services, and oil and gas sectors reported numerous indicators, most companies from the electricity, retail, and food industries, on the other hand, did not use the GRI indicators. Furthermore, among the 79 indicators listed in the GRI G3, all were used at least once. While the GRI's economic indicators were widely reported in many sectors, there were many differences in the environmental indicators as well as in the various categories of social indicators that were reported.

Samuel et al. (2013), instead, provide an insight into sustainable production indicators used only by the petrochemical industry in Malaysia. Results indicate that the majority of the indicators disclosed are related to compliance, performance and environmental impacts. The indicators related to supply chain and product life cycle were weakly reported, and none of the indicators disclosed fell within the category that addresses sustainability issues in terms of the ecological carrying capacity.

In the same sectoral perspective, Alazzani and Wan-Hussin (2013) analyse how the use of a voluntary standard assessment system for environmental reporting could help mitigate the damage caused by oil and gas companies to developing nations. The study evaluates the environmental practices of eight oil and gas companies, and content analysis of their environmental reports 2009 indicates that they made reasonable efforts to disclose their environmental performance in accordance with the GRI G3 Guidelines.

Overall, then, there are very few studies that specifically investigate the disclosure of GRI indicators in sustainability reports of companies. This lack drove us to further explore this subject.

\section{Empirical Analysis}

\subsection{Sample}

The study sample is made up of all 292 companies, both Italian and foreign, listed on the Italian Stock Exchange on March 31, 2014. The companies are analysed according to their relevant "industry" membership as identified on the Italian Stock Exchange website.

In order to verify the number and type of economic, environmental, and social indicators included in the GRI-based sustainability reports compiled in 2012 by the companies listed on the Italian Stock Exchange, it was first necessary to verify how many of the listed companies produced such reports. Table 1 provides the final sample analysed.

Table 1. Sample

\begin{tabular}{cr}
\hline Initial sample & 292 \\
\hline$\bullet \quad$ Companies suspended from listing on the date of the analysis & 7 \\
$\bullet \quad$ Companies that produce voluntary reports but not GRI-based & 17 \\
$\bullet \quad$ Companies that produce no voluntary reports & 221 \\
\hline Final sample analysed & 47 \\
\hline
\end{tabular}

In Table 2, the 47 firms in the sample analysis are divided according to industry sector, the GRI guidelines adopted and GRI Application Level (AL).

Table 2 shows that the Financial Services sector contains the largest number of companies, followed closely by the Industrial sector. Meanwhile, no enterprises operating within the Basic Materials and the Health Care sectors compiled GRI-based sustainability reports. Furthermore, the Table shows which GRI Guidelines the companies adopted, revealing a widespread use of the G3.1 (30 companies out of 47), primarily in the Utilities sector where they were used by all eight companies in question, and in the Consumer Goods and Industrial sectors where they were used by most of the companies. With regard to the $\mathrm{AL}$, there is a prevalence of the $\mathrm{A}+$ level, both for companies that adopt the G3.1 (18 companies out of 30), as well as for those that adopt the G3 (9 companies out of 17). The $\mathrm{B}+$ level is the second most popular, again for both of the guidelines, although the number of companies is much lower compared to the former level. 
Table 2. Number of companies by industry sector, GRI guidelines adopted and AL

\begin{tabular}{|c|c|c|c|c|c|c|c|c|c|c|c|c|c|c|c|c|c|}
\hline \multirow{2}{*}{ Industry Sector } & \multirow{2}{*}{$\begin{array}{c}\text { Total } \\
\text { companies } \\
\text { GRI }\end{array}$} & \multicolumn{7}{|c|}{$\begin{array}{c}\text { GRI G3 } \\
\text { AL }\end{array}$} & \multirow{2}{*}{$\begin{array}{c}\text { Total } \\
\text { companies } \\
\text { G3 }\end{array}$} & \multicolumn{7}{|c|}{$\begin{array}{c}\text { GRI G3.1 } \\
\text { AL }\end{array}$} & \multirow{2}{*}{$\begin{array}{c}\begin{array}{c}\text { Total } \\
\text { companies }\end{array} \\
\text { G3.1 }\end{array}$} \\
\hline & & $\overline{\mathrm{A}+}$ & A & $\mathrm{B}+$ & $\mathrm{B}$ & $\mathrm{C}+$ & $\mathrm{C}$ & und. & & $\mathrm{A}+$ & A & $\mathrm{B}+$ & $\mathrm{B}$ & $\mathrm{C}+$ & $\mathrm{C}$ & und. & \\
\hline Financial Services & 13 & 4 & & 1 & & 1 & 1 & & 7 & 2 & 2 & 1 & & & & 1 & 6 \\
\hline Industrial & 10 & 2 & & & & & 1 & & 3 & 4 & & 2 & & 1 & & & 7 \\
\hline Utilities & 8 & & & & & & & & 0 & 8 & & & & & & & 8 \\
\hline Consumer Goods & 5 & 1 & & & & & & & 1 & 2 & & 1 & & & 1 & & 4 \\
\hline Consumer Services & 5 & & & 1 & 1 & & & & 2 & 1 & & 1 & & & & 1 & 3 \\
\hline Oil and Gas & 4 & & & 1 & & & & 1 & 2 & 1 & 1 & & & & & & 2 \\
\hline Technology & 1 & 1 & & & & & & & 1 & & & & & & & & 0 \\
\hline Telecommunications & 1 & 1 & & & & & & & 1 & & & & & & & & 0 \\
\hline Basic materials & 0 & & & & & & & & 0 & & & & & & & & 0 \\
\hline Health Care & 0 & & & & & & & & 0 & & & & & & & & 0 \\
\hline Total companies & 47 & 9 & 0 & 3 & 1 & 1 & 2 & 1 & 17 & 18 & 3 & 5 & 0 & 1 & 1 & 2 & 30 \\
\hline
\end{tabular}

\subsection{Methodology}

Our analysis focused on the sustainability reports of the sample companies, all dating from 2012 and present on their corporate websites. To answer our research questions, we studied the GRI content index present in the corporate sustainability reports of the sample (43 cases) and, when absent, referred to the GRI index available on each corporate website (4 cases). The verification of economic, environmental, and social indicators in the sustainability reports was performed by using content analysis (Krippendorff, 2004). The presence in the sustainability reports of each indicator included in the GRI index was verified in relation to the page(s) indicated within the GRI index. Thus, an excel spreadsheet was created which catalogued the indicators included within the GRI G3 (79) and G3.1 (84), (Note 2) codifying an indicator's presence in the report with the value "1" and its absence with the value "0". Each indicator was given the same "weight" (Marston \& Shrives, 1991). To improve the reliability of data analysed, the verification of the GRI index and of the content of sustainability reports in the section relating to indicators, was carried out by two separate researchers. The results were then compared and the final data codification table was compiled.

\section{Results}

\subsection{The Categories of Performance Indicators in Sustainability Reports}

This section presents an overview of the different categories of economic, environmental and social indicators, distinguishing between core and additional indicators. See Table 3.

Table 3. Descriptive statistics: number and category of GRI indicators disclosed in sustainability reports

\begin{tabular}{|c|c|c|c|c|c|c|c|}
\hline GRI Indicators & $\begin{array}{l}\text { Expected } \\
\text { Frequency }\end{array}$ & $\begin{array}{l}\text { Average } \\
\text { Frequency }\end{array}$ & $\begin{array}{l}\text { Expected F./ } \\
\text { Average F. }\end{array}$ & $\begin{array}{l}\text { Standard } \\
\text { Deviation }\end{array}$ & Minimum & Maximum & Median \\
\hline $\mathrm{EC}$ & $0-9$ & 6,8 & $76 \%$ & 1,99 & 1 & 9 & 7 \\
\hline Core & $0-7$ & 5,9 & $84 \%$ & 1,5 & 1 & 7 & 7 \\
\hline Additional & $0-2$ & 0,9 & $45 \%$ & 0,8 & 0 & 2 & 1 \\
\hline $\mathrm{EN}$ & $0-30$ & 19,5 & $65 \%$ & 6,4 & 5 & 30 & 21 \\
\hline Core & $0-17$ & 12,8 & $75 \%$ & 3,8 & 4 & 17 & 14 \\
\hline Additional & $0-13$ & 6,7 & $51 \%$ & 3,6 & 0 & 13 & 7 \\
\hline LA & $0-15$ & 12,3 & $82 \%$ & 2,83 & 3 & 15 & 14 \\
\hline Core & $0-10$ & 8,7 & $87 \%$ & 1,5 & 3 & 10 & 9 \\
\hline
\end{tabular}




\begin{tabular}{|c|c|c|c|c|c|c|c|}
\hline Additional & $0-5$ & 3,6 & $72 \%$ & 1,6 & 0 & 5 & 4 \\
\hline HR & $0-11$ & 6,7 & $61 \%$ & 3,05 & 0 & 11 & 6 \\
\hline Core & $0-9$ & 6 & $67 \%$ & 2,6 & 0 & 9 & 6 \\
\hline Additional & $0-2$ & 0,7 & $35 \%$ & 0,8 & 0 & 2 & 0 \\
\hline SO & $0-10$ & 7,1 & $71 \%$ & 2,66 & 2 & 10 & 7 \\
\hline Core & $0-8$ & 5,8 & $73 \%$ & 2,1 & 2 & 8 & 6 \\
\hline Additional & $0-2$ & 1,3 & $65 \%$ & 0,8 & 0 & 2 & 2 \\
\hline PR & $0-9$ & 5,5 & $62 \%$ & 2,81 & 0 & 9 & 5 \\
\hline Core & $0-4$ & 3 & $75 \%$ & 1,3 & 0 & 4 & 4 \\
\hline Additional & $0-5$ & 2,5 & $50 \%$ & 1,8 & 0 & 5 & 2 \\
\hline $\begin{array}{l}\text { Total Standard } \\
\text { Indicators }\end{array}$ & $0-84$ & 58 & $69 \%$ & 17,26 & 17 & 83 & 61 \\
\hline Core & $0-55$ & 42,2 & $77 \%$ & 11,2 & 13 & 55 & 47 \\
\hline Additional & $0-29$ & 15,8 & $54 \%$ & 7,6 & 0 & 29 & 17 \\
\hline
\end{tabular}

As Table 3 illustrates, all of the indicator categories are, on average, well represented in the reports of the selected companies (with percentages exceeding 60\%). This trend is mainly generated by the core indicators of all categories, with percentages of reporting close to or above $70 \%$, while the additional indicators generally had much lower percentages, starting from values of $35 \%$.

The Social Indicators related to LA, with an average of 12 (or 80\%), represent the most frequently mentioned category in the sustainability reports (with values ranging from a minimum of 3 to a maximum of 15). The next most common category is that of EC indicators $(76 \%)$ which feature a higher concentration around the average value (standard deviation of 1.99) than the others. The EN indicators, on the other hand, have an average frequency of approximately $67 \%$ and the highest standard deviation (6.4).

These results are replicated, and even improved, in the disclosure of the core indicators.

The core indicators LA and EC show the highest percentages of disclosure (with values of $87 \%$ and $84 \%$, respectively) compared to all other categories of core indicators. The core indicators EN and PR follow, both with values of $75 \%$. As regards the additional indicators, however, only the LA maintain the top position (with $72 \%$ ), followed by additional indicators SO (with $65 \%$ ).

On the other hand, the other categories of Social Indicators (core and additional), related to HR and PR, are the ones reported on average less frequently (with percentages of $61 \%$ and $62 \%$, respectively), highlighting cases of companies that report none of these performance measures (minimum values of 0 ).

Overall, the average and the median values in all of these indicator categories are remarkably close to one another, thus revealing a considerable symmetry in the distribution of these indicators in each category. Incidentally, half of the categories have median values higher than their average values, indicating that more than half of the companies studied report a higher number of indicators from each category than the average. The opposite is true only for the HR, SO, and PR indicators, in which the average values are higher than the median. This trend is also confirmed, except for indicators $\mathrm{SO}$, in the analysis of additional indicators. The median values are higher than the average for less than 5 of the 7 categories of indicators. In the core indicators, however, all categories of indicators have a numerosity above average, as is evidenced by the median values being always higher than the average values.

Of particular interest are the values for the Total Indicators. The total number of indicators reported by the companies ranges from a minimum of 17 to a maximum of 83, with a markedly larger difference between the average values (58) and the median values (61) as compared to the other categories of indicators. Furthermore, the standard deviation of 17.26 indicates a significant contrast between companies in their disclosure of Total Indicators. Similar considerations may also be made for core and additional indicators within the category of Total Indicators, specifying that such differences between mean and median values, compared to other categories of indicators, rise significantly for the core indicators and are reduced for additional indicators. This confirms the greater importance that all companies give to the disclosure of core indicators in all the categories analysed. 


\subsection{Performance Indicators by Industry}

Table 4 shows the average of the indicators based on the sector of activity, again distinguishing between core and additional indicators.

\begin{tabular}{|c|c|c|c|c|c|c|c|c|c|c|c|c|c|c|c|c|c|}
\hline GRI Indicators & $\begin{array}{c}\text { Financial } \\
\text { Services }\end{array}$ & $\%$ & Industrial & $\%$ & Utilities & $\%$ & $\begin{array}{l}\text { Consumer } \\
\text { Goods }\end{array}$ & $\%$ & $\begin{array}{r}\text { Cons } \\
\text { Serv }\end{array}$ & $\begin{array}{l}\text { umer } \\
\text { ices }\end{array}$ & $\%$ & $\begin{array}{l}\text { Oil and } \\
\text { Gas }\end{array}$ & $\%$ & Technology & $\%$ & $\begin{array}{l}\text { Telecommu- } \\
\text { nications }\end{array}$ & $\%$ \\
\hline $\mathrm{EC}$ & 7,15 & $79 \%$ & 7 & $78 \%$ & 7,88 & $88 \%$ & 6,6 & $73 \%$ & 5 & & $56 \%$ & 7,25 & $81 \%$ & 7 & $78 \%$ & 1 & $11 \%$ \\
\hline Core & 6,07 & $87 \%$ & 6,1 & $87 \%$ & 7 & $100 \%$ & 5,06 & $72 \%$ & & 4,8 & $69 \%$ & 6,25 & $89 \%$ & 5 & $71 \%$ & 1 & $14 \%$ \\
\hline Additional & 1,08 & $54 \%$ & 0,9 & $45 \%$ & 0,88 & $44 \%$ & 1 & $50 \%$ & & 0,2 & $10 \%$ & 1 & $50 \%$ & 2 & $100 \%$ & 0 & $0 \%$ \\
\hline EN & 16,3 & $54 \%$ & 21 & $70 \%$ & 24,63 & $82 \%$ & 20,4 & $68 \%$ & 13,8 & & $46 \%$ & 23,25 & $78 \%$ & 24 & $80 \%$ & 12 & $40 \%$ \\
\hline Core & 11,1 & $65 \%$ & 13,7 & $81 \%$ & 15,25 & $90 \%$ & 13,8 & $81 \%$ & & 10,2 & $60 \%$ & 14,75 & $87 \%$ & 15 & $88 \%$ & 7 & $41 \%$ \\
\hline Additional & 5,2 & $40 \%$ & 7,3 & $56 \%$ & 9,38 & $72 \%$ & 6,6 & $51 \%$ & & 3,6 & $28 \%$ & 8,5 & $65 \%$ & 9 & $69 \%$ & 5 & $38 \%$ \\
\hline LA & 12,2 & $81 \%$ & 12,3 & $82 \%$ & 13,25 & $88 \%$ & 11,8 & $79 \%$ & 11,8 & & $79 \%$ & 14 & $93 \%$ & 10 & $67 \%$ & 6 & $40 \%$ \\
\hline Core & 8,6 & $86 \%$ & 8,7 & $87 \%$ & 9,5 & $95 \%$ & 8 & $80 \%$ & & 8,2 & $82 \%$ & 9,5 & $95 \%$ & 8 & $80 \%$ & 5 & $50 \%$ \\
\hline Additional & 3,6 & $72 \%$ & 3,6 & $72 \%$ & 3,75 & $75 \%$ & 3,8 & $76 \%$ & & 3,6 & $72 \%$ & 4,5 & $90 \%$ & 2 & $40 \%$ & 1 & $20 \%$ \\
\hline HR & 5,8 & $53 \%$ & 6,6 & $60 \%$ & 8,25 & $75 \%$ & 6,6 & $60 \%$ & 4 & & $36 \%$ & 9,75 & $89 \%$ & 7 & $64 \%$ & 6 & $55 \%$ \\
\hline Core & 5,4 & $60 \%$ & 5,9 & $66 \%$ & 7,12 & $79 \%$ & 6 & $67 \%$ & & 4 & $44 \%$ & 8 & $89 \%$ & 7 & $78 \%$ & 6 & $67 \%$ \\
\hline Additional & 0,4 & $20 \%$ & 0,7 & $35 \%$ & 1,13 & $57 \%$ & 0,6 & $30 \%$ & & 0 & $0 \%$ & 1,75 & $88 \%$ & 0 & $0 \%$ & 0 & $0 \%$ \\
\hline SO & 6,4 & $64 \%$ & 7,3 & $73 \%$ & 9,1 & $91 \%$ & 7,4 & $74 \%$ & 5,2 & & $52 \%$ & 8,25 & $83 \%$ & 5 & $50 \%$ & 2 & $20 \%$ \\
\hline Core & 5,2 & $65 \%$ & 6,1 & $76 \%$ & 7,5 & $94 \%$ & 6 & $75 \%$ & & 4,2 & $53 \%$ & 6,25 & $78 \%$ & 5 & $63 \%$ & 2 & $25 \%$ \\
\hline Additional & 1,2 & $60 \%$ & 1,2 & $60 \%$ & 1,6 & $80 \%$ & 1,4 & $70 \%$ & & 1 & $50 \%$ & 2 & $100 \%$ & 0 & $0 \%$ & 0 & $0 \%$ \\
\hline PR & 5,5 & $61 \%$ & 4,3 & $48 \%$ & 6,1 & $68 \%$ & 6,6 & $73 \%$ & 5,2 & & $58 \%$ & 8,25 & $92 \%$ & 3 & $33 \%$ & 3 & $33 \%$ \\
\hline Core & 2,8 & $70 \%$ & 2,8 & $70 \%$ & 3,4 & $85 \%$ & 3,2 & $80 \%$ & & 2,8 & $70 \%$ & 4 & $100 \%$ & 2 & $50 \%$ & 2 & $50 \%$ \\
\hline Additional & 2,7 & $54 \%$ & 1,5 & $30 \%$ & 2,7 & $54 \%$ & 3,4 & $68 \%$ & & 2,4 & $48 \%$ & 4,25 & $85 \%$ & 1 & $20 \%$ & 1 & $20 \%$ \\
\hline $\begin{array}{l}\text { Total (Standard) } \\
\text { Indicators }\end{array}$ & 53,5 & $64 \%$ & 58,5 & $70 \%$ & 69,25 & $82 \%$ & 59,4 & $71 \%$ & 45 & & $54 \%$ & 70,75 & $84 \%$ & 56 & $67 \%$ & 30 & $36 \%$ \\
\hline Core & 39,2 & $71 \%$ & 43,3 & $79 \%$ & 49,75 & $90 \%$ & 42,6 & $77 \%$ & & 34,2 & $62 \%$ & 48,75 & $89 \%$ & 42 & $76 \%$ & 23 & $42 \%$ \\
\hline Additional & 14,3 & $49 \%$ & 15,2 & $52 \%$ & 19,50 & $67 \%$ & 16,8 & $58 \%$ & & 10,8 & $37 \%$ & 22 & $76 \%$ & 14 & $48 \%$ & 7 & $24 \%$ \\
\hline
\end{tabular}

As regards Total (Standard) Indicators, it is possible to observe that most of the sectors report, on average, more than $60 \%$ of the total reportable. The only exceptions are the Telecommunications and Utilities sectors. The highest number of indicators regarding Total Indicators is reported in the Oil and Gas (84\%) and Utilities (82\%) sectors, while the lowest number of indicators is reported in the Telecommunications sector (with only $36 \%$ ).

These sectoral results are replicated also in the numbers of the core and additional indicators in the category of Total Indicators. Specifically, in the disclosure of the total core indicators, except for Telecommunications and Consumer Services sectors, the others show more than $70 \%$ of these indicators, with the Oil and Gas and Utilities sectors reporting up to $90 \%$. Instead, as regards disclosure of the total additional indicators, the others report less than $60 \%$, with the exception of the last two sectors, confirming the relatively lower importance, given to them by the sectors compared to the core indicators.

A substantially similar trend regards the disclosure of EC and EN indicators. For EC indicators, most sectors, primarily those of Utilities (with 88\%) and Oil and Gas (with 81\%), have high percentages of reporting. with the exception of the Telecommunications sector that shows only 1 (out of a total of 9) and this is a core indicator. The best performers as regards the disclosure of EN indicators are again the same two sectors, to which is added the Technology sector with $80 \%$ of the EN indicators, while the Telecommunications sector retains the last position with only $40 \%$ of the total. This trend of sectorial disclosure of EC and EN indicators also characterizes the core and additional indicators of these categories. The Utilities sector, in particular, reports $100 \%$ of EC core indicators and $90 \%$ of EN core indicators.

In the disclosure of EC and EN additional indicators, instead, there are some differences between sectors. In the EN additional indicators, the trend of sectorial disclosure reflects that seen for the EN core indicators, with relatively low percentages, though the Technology sector reports $100 \%$ of these, while the other sectors report approximately $50 \%$ of those that could be reported. Only the Telecommunications sector does not report any of these indicators, while the Consumer Services sector reports only $10 \%$.

Finally, as regards the sectorial disclosure of social indicators, the average values of the 4 aspects in which they are divided once again highlights an alternation at the top between the Oil and Gas and Utilities sectors.

These are followed by the Consumer Goods sector only in the most numerous reporting of PR indicators (with $73 \%$ ). The last places, however, are almost always occupied by the Telecommunications sector that is flanked by 
the Consumer Services only for the PR indicators. The worst performance is by the Consumer Services sector as regards Social indicators related to Human Rights (HR), with $36 \%$ of these reported.

A comparison between the various aspects of social indicators among the different sectors, confirms the previous statement regarding the increased use, in all sectors, of the LA indicators compared to the others in the social category. The LA indicators are exceeded only by the SO indicators (91\%), in the Utilities sector, and by the HR indicators $(55 \%)$ in the Telecommunications sector.

This trend in the sectorial disclosure of the four aspects of social indicators also exists for this category's core indicator. In fact, in all sectors, the reporting of the LA core indicators dominates compared to the other social indicators, with maximum levels (95\%) in the Utilities and Oil and Gas sectors. The additional indicators for the four aspects of social indicators have relatively lower percentages of disclosure than the core indicators of this category, as well as also those shown for EC and EN additional indicators. The lack of reporting of HR additional indicators in the Consumer Services, Telecommunications and Technology sectors is also noticeable. These last two sectors do not even show the SO additional indicators. In all sectors, the percentage reporting of LA additional indicators prevail over the remaining aspects of social indicators. The Oil and Gas sector has the highest percentages in all four aspects of additional indicators of the social category. Moreover, the already high disclosure of LA additional indicators (equal to $90 \%$ ) is exceeded by the $100 \%$ use of SO additional indicators only in this sector.

\subsubsection{The Use of the Different Categories of Performance Indicators}

In the following Tables 5, 6 and 7 we present a more detailed descriptive analysis by illustrating the employment of all the types of GRI indicators by industry sector, and total of companies in the sample. Core and additional indicators of each category of GRI indicators are marked in the tables in gray and black respectively. Table 5 shows the frequency of use of each EC indicator by sector and total of companies.

Table 5. EC indicators by industry sector and total of companies

\begin{tabular}{lccccccccc}
\hline Industry Sector & EC 1 & EC 2 & EC 3 & EC 4 & EC 5 & EC 6 & EC 7 & EC 8 & EC 9 \\
\hline Financial Services (13) & 13 & 8 & 11 & 11 & 7 & 12 & 11 & 13 & 7 \\
Industry (10) & 10 & 8 & 9 & 9 & 4 & 8 & 7 & 10 & 5 \\
Utilities (8) & 8 & 8 & 8 & 8 & 3 & 8 & 8 & 8 & 4 \\
Consumer Goods(5) & 5 & 3 & 4 & 4 & 3 & 3 & 4 & 5 & 2 \\
Consumer Services (5) & 5 & 3 & 4 & 2 & 0 & 3 & 3 & 4 & 1 \\
Oil and Gas (4) & 4 & 4 & 3 & 3 & 1 & 4 & 3 & 4 & 3 \\
Technology (1) & 1 & 1 & 0 & 0 & 1 & 1 & 1 & 1 & 1 \\
Telecommunications (1) & 0 & 1 & 0 & 0 & 0 & 0 & 0 & 0 & 0 \\
\hline \multicolumn{1}{c}{ Total Indicators } & 46 & 36 & 39 & 37 & 19 & 39 & 37 & 45 & 23 \\
\hline
\end{tabular}

The Table shows a widespread use of EC indicators in many sectors with a higher prevalence in the percentages of use of core indicators than additional ones. The EC2, EC3, EC4, EC6, EC7 indicators have a percentage of use around $80 \%$. The EC1 indicator, which provides information on the economic value generated and distributed, is reported by companies from all sectors (98\%) except Telecommunications. A substantially similar trend regards the EC8 indicator (on the impact of infrastructure investment and services provided primarily for public benefit) with $98 \%$ disclosure. Only two companies belonging to the Consumer Services and Telecommunications sectors fail to report this indicator.

Comparatively, the behaviour of the companies in the Utilities sector is excellent, showing full coverage (100\%) of the EC core indicators, although they do not report the EC5 and EC9 additional indicators. The disclosure in the Oil and Gas sector is also significant, with the four companies producing a similarly full coverage in four EC core indicators (EC1, EC2, EC6, EC8).

On the other hand, the EC5 additional indicator (on the range of ratios of standard entry level wage by gender 
compared to local minimum wage at significant locations of operation) is the one with the lowest frequency of use by companies (40\%). In some sectors, such as Consumer Services and Telecommunications, this indicator is used by no companies. The other additional indicator, EC9 (relating to indirect economic impacts and the extent of impacts) also has a percentage of disclosure below 50\%. The companies in the Technology and Oil and Gas sectors are those that, in relative terms, reported this indicator most frequently, while those of the Consumer Services and Telecommunications sectors provide comparatively minor disclosure. It should be emphasized that the one company belonging to this sector, reports only the EC2 core indicator (on the financial implications and other risks and opportunities related to climate change).

Table 6 shows the frequency of use of each EN indicator by sector and total of companies.

Table 6. EN Indicators by Industry Sector and Total of Companies

\begin{tabular}{|c|c|c|c|c|c|c|c|c|c|c|c|c|c|c|c|c|c|c|c|c|c|c|c|c|c|c|c|c|c|c|}
\hline Industry Sector & $\begin{array}{c}\text { EN } \\
1\end{array}$ & $\begin{array}{c}\text { EN } \\
2\end{array}$ & $\begin{array}{c}\text { EN } \\
3\end{array}$ & $\begin{array}{c}\mathrm{EN} \\
4\end{array}$ & $\begin{array}{c}\text { EN } \\
5\end{array}$ & $\begin{array}{c}\text { EN } \\
6\end{array}$ & $\begin{array}{c}\text { EN } \\
7\end{array}$ & $\begin{array}{c}\text { EN } \\
8\end{array}$ & $\begin{array}{c}\text { EN } \\
9\end{array}$ & $\begin{array}{c}\text { EN } \\
10\end{array}$ & $\begin{array}{c}\text { EN } \\
11\end{array}$ & $\begin{array}{l}\text { EN } \\
12\end{array}$ & $\begin{array}{c}\text { EN } \\
13\end{array}$ & $\begin{array}{r}\text { EN } \\
14\end{array}$ & $\begin{array}{l}\text { EN } \\
15\end{array}$ & $\begin{array}{r}\text { EN } \\
16\end{array}$ & $\begin{array}{l}\text { EN } \\
17\end{array}$ & $\begin{array}{c}\text { EN } \\
18\end{array}$ & $\begin{array}{l}\text { EN } \\
19\end{array}$ & $\begin{array}{c}\mathrm{EN} \\
20\end{array}$ & $\begin{array}{c}\text { EN } \\
21\end{array}$ & $\begin{array}{l}\text { EN } \\
22\end{array}$ & $\begin{array}{l}\text { EN } \\
23\end{array}$ & $\begin{array}{l}\text { EN } \\
24\end{array}$ & $\begin{array}{c}\text { EN } \\
25\end{array}$ & $\begin{array}{l}\text { EN } \\
26\end{array}$ & $\begin{array}{l}\text { EN } \\
27\end{array}$ & $\begin{array}{r}\text { EN } \\
28\end{array}$ & $\begin{array}{l}\text { EN } \\
29\end{array}$ & $\begin{array}{l}\text { EN } \\
30\end{array}$ \\
\hline $\begin{array}{l}\text { Financial } \\
\text { Services (13) }\end{array}$ & 10 & 9 & 13 & 12 & 11 & 10 & 11 & 13 & 5 & 3 & 6 & 5 & 0 & 1 & 0 & 12 & 8 & 9 & 7 & 7 & 7 & 12 & 2 & 3 & 0 & 12 & 1 & 8 & 10 & 5 \\
\hline Industry (10) & 8 & 7 & 10 & 9 & 8 & 8 & 5 & 10 & 5 & 7 & 9 & 6 & 5 & 6 & 1 & 10 & 7 & 8 & 6 & 7 & 7 & 10 & 8 & 3 & 1 & 9 & 5 & 9 & 8 & 8 \\
\hline Utilities (8) & 8 & 5 & 8 & 8 & 8 & 7 & 5 & 8 & 5 & 5 & 8 & 8 & 7 & 7 & 2 & 8 & 7 & 8 & 8 & 8 & 7 & 8 & 7 & 4 & 4 & 8 & 0 & 8 & 6 & 7 \\
\hline $\begin{array}{l}\text { Consumer } \\
\text { Goods (5) }\end{array}$ & 3 & 4 & 5 & 4 & 4 & 5 & 3 & 5 & 2 & 1 & 4 & 3 & 2 & 2 & 1 & 4 & 3 & 4 & 4 & 4 & 4 & 5 & 4 & 2 & 1 & 5 & 4 & 4 & 3 & 3 \\
\hline $\begin{array}{l}\text { Consumer } \\
\text { Services (5) }\end{array}$ & 4 & 3 & 5 & 5 & 3 & 2 & 2 & 5 & 2 & 2 & 1 & 0 & 0 & 1 & 0 & 5 & 2 & 3 & 2 & 1 & 2 & 5 & 1 & 1 & 0 & 4 & 3 & 3 & 2 & 0 \\
\hline Oil and Gas (4) & 4 & 1 & 4 & 4 & 4 & 3 & 3 & 4 & 4 & 3 & 3 & 4 & 2 & 3 & 0 & 4 & 3 & 4 & 2 & 4 & 4 & 4 & 4 & 3 & 2 & 4 & 2 & 4 & 0 & 3 \\
\hline Technology (1) & 1 & 1 & 1 & 1 & 1 & 1 & 1 & 1 & 0 & 1 & 0 & 0 & 0 & 0 & 0 & 1 & 1 & 1 & 1 & 1 & 1 & 1 & 1 & 1 & 1 & 1 & 1 & 1 & 1 & 1 \\
\hline $\begin{array}{l}\text { Telecommuni- } \\
\text { cations (1) }\end{array}$ & 0 & 0 & 1 & 0 & 1 & 1 & 1 & 1 & 0 & 0 & 0 & 0 & 0 & 0 & 0 & 1 & 0 & 1 & 1 & 0 & 0 & 1 & 1 & 0 & 0 & 1 & 0 & 0 & 1 & 0 \\
\hline $\begin{array}{r}\text { Total Indicators } \\
\text { (out of } 47 \text { companies) }\end{array}$ & 38 & 30 & 47 & 43 & 40 & 37 & 31 & 47 & 23 & 22 & 31 & 26 & 16 & 20 & 4 & 45 & 31 & 38 & 31 & 32 & 32 & 46 & 28 & 17 & 9 & 44 & 16 & 37 & 31 & 27 \\
\hline$\%$ & $\begin{array}{l}81 \\
\%\end{array}$ & $\begin{array}{l}64 \\
\%\end{array}$ & $\begin{array}{c}100 \\
\%\end{array}$ & $\begin{array}{l}91 \\
\%\end{array}$ & $\begin{array}{l}85 \\
\%\end{array}$ & $\begin{array}{l}79 \\
\%\end{array}$ & $\begin{array}{l}66 \\
\%\end{array}$ & $\begin{array}{c}100 \\
\%\end{array}$ & $\begin{array}{l}49 \\
\%\end{array}$ & $\begin{array}{l}47 \\
\%\end{array}$ & $\begin{array}{l}66 \\
\%\end{array}$ & $\begin{array}{l}55 \\
\%\end{array}$ & $\begin{array}{l}34 \\
\%\end{array}$ & $\begin{array}{l}43 \\
\%\end{array}$ & $\begin{array}{c}9 \\
\%\end{array}$ & $\begin{array}{l}96 \\
\%\end{array}$ & $\begin{array}{l}66 \\
\%\end{array}$ & $\begin{array}{l}81 \\
\%\end{array}$ & $\begin{array}{l}66 \\
\%\end{array}$ & $\begin{array}{l}68 \\
\%\end{array}$ & $\begin{array}{l}68 \\
\%\end{array}$ & $\begin{array}{l}98 \\
\%\end{array}$ & $\begin{array}{l}60 \\
\%\end{array}$ & $\begin{array}{l}36 \\
\%\end{array}$ & $\begin{array}{l}19 \\
\%\end{array}$ & $\begin{array}{l}94 \\
\%\end{array}$ & $\begin{array}{l}34 \\
\%\end{array}$ & $\begin{array}{l}79 \\
\%\end{array}$ & $\begin{array}{l}66 \\
\%\end{array}$ & $\begin{array}{l}57 \\
\%\end{array}$ \\
\hline
\end{tabular}

As shown in Table 6, there are some differences between sectors in the disclosure of the EN core and additional indicators.

In absolute terms, the indicators most represented are EN1, EN3, EN4, EN5, EN6, EN8, EN16, EN18, EN22, EN26, EN28 with around $80 \%$ or higher disclosure. This finding is significant especially if we observe that of these, only the EN5, EN6, EN18, EN26, EN28 indicators are additional indicators. The core indicators EN3 (Direct energy consumption by primary Energy source) and EN8 (Total water withdrawal by source) are those reported by the companies of all sectors $(100 \%)$.

A substantially similar trend regards the EN21 indicator (Total water discharge by quality and destination) (98\%), which is not employed by a single company of the Financial Services sector, and the EN16 indicator (Total direct and indirect greenhouse gas emissions) (94\%), employed neither by any company of the Financial Services sector nor by any company of the Consumer Goods sector. The additional indicator EN 15 (on the Number of IUCN Red List species and national conservation list species with habitats in areas affected by operations, by level of extinction risk), instead, is the one with the lowest frequency of use by the companies (9\%). The same applies to the additional indicator EN25 (a qualitative indicator to describe the impacts of an organization's discharges of water and runoff) with only $19 \%$ disclosure.

Overall, as regards the analysis of the sectoral disclosure in the EN indicators, the behaviour of the Utilities and Oil and Gas sectors is particularly significant. Both sustainability reports show a full coverage $(100 \%)$ for about half of all GRI environmental indicators, some of which, like the EN5 and EN18, are only additional indicators.

Table 7 shows the frequency of use of Social Indicators related to LA, HR, SO and PR, by sector of activity and total companies. 
Table 7. Social Indicators by Industry Sector and Total Companies

\begin{tabular}{|c|c|c|c|c|c|c|c|c|c|c|c|c|c|c|c|c|c|c|c|c|c|c|c|c|c|c|}
\hline \multirow[t]{2}{*}{ Industry Sector } & LA & LA & LA & LA & LA & LA & LA & LA & LA & LA & LA & LA & LA & LA & LA & HR & $\mathrm{HR}$ & $\mathrm{HR}$ & $\mathrm{HR}$ & HR & HR & $\mathrm{HR}$ & $\mathrm{HR}$ & HR & HR & HR \\
\hline & & 2 & & 4 & 5 & & 7 & & 9 & 10 & 11 & & 13 & & & 1 & & 3 & 4 & & 6 & & 8 & & & 11 \\
\hline $\begin{array}{l}\text { Financial } \\
\text { Services (13) }\end{array}$ & 13 & 13 & 10 & 11 & 9 & 8 & 12 & 12 & 8 & 13 & 10 & 11 & 13 & 11 & 5 & 8 & 10 & 8 & 11 & 8 & 8 & 8 & 3 & 3 & 4 & 5 \\
\hline Industry (10) & 10 & 9 & 8 & 10 & 9 & 6 & 10 & 8 & 8 & 10 & 8 & 6 & 10 & 8 & 3 & 6 & 8 & 6 & 8 & 8 & 8 & 8 & 3 & 4 & 3 & 4 \\
\hline Utilities (8) & 8 & 8 & 6 & 8 & 8 & 5 & 8 & 8 & 6 & 8 & 5 & 8 & 8 & 8 & 4 & 7 & 8 & 5 & 7 & 8 & 8 & 8 & 3 & 6 & 2 & 4 \\
\hline $\begin{array}{l}\text { Consumer } \\
\text { Goods (5) }\end{array}$ & 5 & 4 & 4 & 4 & 4 & 4 & 5 & 4 & 3 & 5 & 4 & 4 & 4 & 3 & 2 & 4 & 3 & 2 & 5 & 4 & 4 & 4 & 2 & 1 & 2 & 2 \\
\hline $\begin{array}{l}\text { Consumer } \\
\text { Services (5) }\end{array}$ & 5 & 4 & 3 & 5 & 3 & 4 & 5 & 4 & 3 & 5 & 4 & 4 & 5 & 3 & 2 & 2 & 5 & 0 & 3 & 2 & 3 & 3 & 0 & 0 & 1 & 1 \\
\hline Oil and Gas (4) & 4 & 4 & 4 & 4 & 4 & 3 & 4 & 4 & 3 & 4 & 4 & 4 & 4 & 4 & 2 & 4 & 4 & 2 & 4 & 4 & 4 & 4 & 4 & 3 & 3 & 3 \\
\hline Techonlogy (1) & 1 & 1 & 0 & 1 & 1 & 0 & 1 & 1 & 0 & 1 & 1 & 1 & 1 & 0 & 0 & 1 & 1 & 1 & 1 & 1 & 1 & 1 & 0 & 0 & 0 & 0 \\
\hline $\begin{array}{l}\text { Telecommuni- } \\
\text { cations (1) }\end{array}$ & 0 & 1 & 0 & 1 & 1 & 0 & 1 & 0 & 1 & 0 & 0 & 0 & 1 & 0 & 0 & 1 & 0 & 1 & 1 & 1 & 1 & 1 & 0 & 0 & 0 & 0 \\
\hline $\begin{array}{r}\text { Total Indicators } \\
\text { (out of } 47 \text { companies) }\end{array}$ & 46 & 44 & 35 & 44 & 39 & 30 & 46 & 41 & 32 & 46 & 36 & 38 & 46 & 37 & 18 & 33 & 39 & 25 & 40 & 36 & 37 & 37 & 15 & 17 & 15 & 19 \\
\hline$\%$ & 98 & 94 & 74 & 94 & 83 & 64 & 98 & 87 & 68 & 98 & 77 & 81 & 98 & 79 & 38 & 70 & 83 & 53 & 85 & 77 & 79 & 79 & 32 & 36 & 32 & 40 \\
\hline$\%$ & $\%$ & $\%$ & $\%$ & $\%$ & $\%$ & $\%$ & $\%$ & $\%$ & $\%$ & $\%$ & $\%$ & $\%$ & $\%$ & $\%$ & $\%$ & $\%$ & $\%$ & $\%$ & $\%$ & $\%$ & $\%$ & $\%$ & $\%$ & $\%$ & $\%$ & $\%$ \\
\hline
\end{tabular}

As Table 7 illustrates, the first aspect of Social indicators is related to Labour (LA). These indicators have a high degree of diffusion in all sectors, with a minimum level of $64 \%$ for the LA6 indicator. It is an additional indicator, which like others of the same type, has percentages of disclosure that are relatively lower than those of the core indicators.

The only exception is the core indicator LA15 (Return to work after parental leave, by gender) with an application rate of $38 \%$.

It should be noted that although indicator LA15 is core, it is not present in the G3 and this could explain its reduced use in reports. Indeed, data show that of 30 companies that adopt G3.1, only 18 companies provide a disclosure of this indicator. We observed that actually 6 core indicators, specifically LA1, LA2, LA4, LA7, LA10, LA13, show disclosure percentages exceeding 94\%. The Oil and Gas, Utilities and Technology sectors are characterized by the highest number of LA indicators reported in their sustainability reports. In fact, there is a coverage of $100 \%$ for most of the indicators in this category although some, such as LA11 and LA12, are just additional. The second category of social indicators, shown in Table 7, regard Human Rights (HR). The dynamics regarding these indicators show that half had a disclosure level of about $80 \%$ while the other half, which included the additional indicator, had disclosure levels below 53\%. The core indicators HR4 (Total number of incidents of discrimination and corrective actions taken) and HR2 (Percentage of significant suppliers, contractors, and other business partners that have undergone human rights screening, and actions taken) are the most reported, while the additional indicator HR8 and core indicator HR10 (which relate respectively to the training provided to staff in relation to human rights and to the assessment activity made by companies to avoid infringement of human rights) are the least reported in the various sectors. The Oil and Gas, Utilities and Technology sectors show the highest number of HR indicators with a coverage close to $100 \%$ in more than half of these, though all these are core indicators.

Table 7. (continues) Social indicators by industry sector and total companies

\begin{tabular}{|c|c|c|c|c|c|c|c|c|c|c|c|c|c|c|c|c|c|c|c|}
\hline \multirow{2}{*}{ Industry Sector } & $\mathrm{SO}$ & $\mathrm{SO}$ & $\mathrm{SO}$ & $\mathrm{SO}$ & $\mathrm{SO}$ & $\mathrm{SO}$ & $\mathrm{SO}$ & $\mathrm{SO}$ & $\mathrm{SO}$ & $\mathrm{SO}$ & PR & PR & PR & PR & PR & PR & PR & PR & PR \\
\hline & 1 & 9 & 10 & 2 & 3 & 4 & 5 & 6 & 7 & 8 & 1 & 2 & 3 & 4 & 5 & 6 & 7 & 8 & 9 \\
\hline $\begin{array}{l}\text { Financial } \\
\text { Services (13) }\end{array}$ & 9 & 3 & 3 & 11 & 12 & 11 & 9 & 7 & 9 & 10 & 8 & 4 & 9 & 6 & 9 & 9 & 9 & 7 & 10 \\
\hline Industry (10) & 9 & 4 & 3 & 9 & 10 & 10 & 8 & 6 & 6 & 8 & 8 & 2 & 6 & 1 & 7 & 6 & 2 & 3 & 8 \\
\hline Utilities (8) & 8 & 6 & 6 & 8 & 8 & 8 & 8 & 7 & 6 & 8 & 7 & 4 & 7 & 2 & 6 & 5 & 3 & 7 & 8 \\
\hline $\begin{array}{l}\text { Consumer } \\
\text { Goods (5) }\end{array}$ & 4 & 3 & 2 & 4 & 4 & 4 & 4 & 3 & 4 & 5 & 4 & 3 & 4 & 3 & 4 & 4 & 3 & 4 & 4 \\
\hline $\begin{array}{l}\text { Consumer } \\
\text { Services (5) }\end{array}$ & 2 & 1 & 1 & 5 & 3 & 3 & 2 & 4 & 1 & 4 & 3 & 2 & 4 & 2 & 3 & 3 & 2 & 3 & 4 \\
\hline Oil and Gas (4) & 3 & 2 & 2 & 3 & 4 & 4 & 3 & 4 & 4 & 4 & 4 & 4 & 4 & 3 & 4 & 4 & 3 & 3 & 4 \\
\hline Technology (1) & 1 & 0 & 0 & 1 & 1 & 1 & 1 & 0 & 0 & 0 & 1 & 0 & 1 & 0 & 1 & 0 & 0 & 0 & 0 \\
\hline $\begin{array}{l}\text { Telecommuni- } \\
\text { cations (1) }\end{array}$ & 0 & 0 & 0 & 1 & 0 & 1 & 0 & 0 & 0 & 0 & 1 & 0 & 1 & 0 & 0 & 0 & 0 & 1 & 0 \\
\hline
\end{tabular}




\begin{tabular}{rllllllllll|llllllllll}
\hline $\begin{array}{r}\text { Total Indicators } \\
\text { (out of 47 companies) }\end{array}$ & 36 & 19 & 17 & 42 & 42 & 42 & 35 & 31 & 30 & 39 & 36 & 19 & 36 & 17 & 34 & 31 & 22 & 28 & 38 \\
\hline$\%$ & $\begin{array}{r}77 \\
\%\end{array}$ & 40 & 36 & 89 & 89 & 89 & 74 & 66 & 64 & 83 & 77 & 40 & 77 & 36 & 72 & 66 & 47 & 60 & 81 \\
$\%$ & $\%$ & $\%$ & $\%$ & $\%$ & $\%$ & $\%$ & $\%$ & $\%$ & $\%$ & $\%$ & $\%$ & $\%$ & $\%$ & $\%$ & $\%$ & $\%$ \\
\hline
\end{tabular}

The third category of social indicators (SO), shown in Table 7, concerns the impact that companies have on the communities in which they operate and how are managed relations with other social institutions. The sectors, for more than half of these indicators, show a disclosure level around or above $80 \%$.

Three core indicators $\mathrm{SO} 2, \mathrm{SO} 3$ and $\mathrm{SO} 4$ (relating to prevention and combating activities of corruption) are the most reported by sectors with a percentage of $89 \%$, while the two additional indicators SO6 and SO7 are those with the lowest percentages. The latter are exceeded only by indicators SO10 and SO9 (pertaining to the relations with the local community) with percentages respectively of 36 and $40 \%$. These indicators are not present in the G3 and this could explain their reduced use in reports although they are both core indicators. Indeed, data show that of 30 companies that adopt G3.1, only 17 companies, for indicator SO10, and 19 companies, for indicator SO9, provide information on these indicators. The Utilities, Oil and Gas, and Technology sectors have the highest number of SO indicators with a coverage of $100 \%$ in most of them. The Oil and Gas sector, in particular, also achieves complete coverage of the two additional indicators. The Telecommunications sector, instead, is that with the lowest disclosure percentages. The fourth and final category of social indicators, shown in Table 7, concerns those relating to Product Responsibility (PR). This is the category in which sectors actually show the lowest level of disclosure with respect to the others. The core indicator PR9 (pertaining to fines envisaged for company violations concerning the providing and use of products or services) is reported with a percentage of $80 \%$. The indicators that follow are PR1, PR3 and PR5 (pertaining to matters relating to health and safety of consumers and labelling) although the latter belongs to the additional type. On the other hand, the least reported indicator is the additional indicator PR4 (non-compliance cases related to the labelling of products/services). The disclosure of the Oil and Gas sector is particularly significant. In fact, this sector shows a comprehensive coverage in all the core indicators of this category, as well as in additional PR2 and PR5 indicators, and close to $100 \%$ in the remaining additional indicators.

\subsection{Indicators and Sector Supplements}

The survey conducted shows that 20 companies (42.5\% of the sample) also report the indicators of the SS. Most of them, however, are concentrated in two sectors. These are the Utilities sector, in which these indicators are reported by all 8 companies present, and Financial Services sector, in which 9 companies (69\% of total sector) provide this additional information. The Industrial sector can then be added to these sectors, with 2 companies ( $20 \%$ of total sector), followed by Oil and Gas, with a single company ( $25 \%$ of total sector).

Observing the number and type of indicators reported and considering the differences in the number of these provided by each SS, there are significant levels of use of SS indicators by the companies that report them across all four sectors.

In the Utilities sector, for example on average $74.2 \%$ of the accountable indicator are reported, with 1 company presenting all 30 indicators provided by the SS (Electric Utilities-EU). The least reported indicator is EU26, shown by only 2 companies, and followed by EU9, reported by 4 companies, while all the other indicators of the SS are reported by at least 5 of 8 companies in the Utilities sector.

There is also a high average in the disclosure of the indicators of the SS in the Financial Services sector (Financial Services-FS) equal to $74.4 \%$ of accountable indicators. Of the 9 companies that report these indicators, a surprising 5 show all 16 indicators provided by the SS, while 3 companies provide less than $50 \%$. The least reported indicator is FS3 that is nonetheless reported by 5 of the 9 companies, while for all other indicators of SS we observe a level of use above $66 \%$. Finally, as regards, the indicators of the SS reported by the 2 companies in the Industrial sector and by the only company in the Oil and Gas sector, in both cases there are high percentages of disclosure. The former report, on average, $87.9 \%$ of the indicators provided by their SS, while the company of the Oil and Gas sector reports all the 14 indicators accountable according to SS.

\section{Conclusions and Discussion}

Few studies have specifically investigated the economic, environmental, and social indicators disclosed in sustainability reports. The purpose of this paper was to verify the number and type of sustainability indicators disclosed in CSR reports produced by Italian listed companies in accordance with the GRI guidelines.

The analysis revealed that the three sets of performance indicators (economic, environmental and social), with a 
prevalence of core indicators, are widely used by Italian companies that produce sustainability reports. This result is certainly the consequence of the high application level of GRI guidelines $(\mathrm{A}+)$, reported by more than half of companies in the sample analysed (about 57\%). The links previously mentioned between the application level and the number of indicators to be reported led us to expect the presence, at least, of core indicators (G3 and G3.1) and of SS indicators (where adopted).

From the point of view of the total numerosity, the reporting of the total of standard indicators reaches values that are indisputably significant (about $70 \%$ of those provided), with disclosure percentages of core indicators equal to $77 \%$ of those accountable. The number of core indicators disclosed increases further if you also consider the indicators reported by companies employing the SS. Among the companies in the sample, those that made the most extensive use of SS are those of the Utilities sector, and over half of the Financial Services sector. The possible use of an SS allows any company that adopts it, to report corporate performance more comprehensively, using specific performance indicators or adding comments to standard indicators.

On average, the category of indicators most frequently reported in sustainability reports of companies of different sectors is that related to Labour Practices and Decent Works (LA). These indicators of social dimensions are followed in number by those of the economic dimension and finally by those of the environmental dimension.

As regards the different sectors, the Oil and Gas and the Utilities sectors showed a higher quality and quantity of indicators than the others. These sectors show a more homogeneous distribution of companies reporting a higher number of indicators from various categories, as opposed to other sectors' reports which are characterized by greater discrepancies in the number and types of indicators reported. The Oil and Gas and the Utilities sectors typically have a significant social and environmental impact (Clarkson et al., 2008; Pattern, 2002; Cho \& Patten, 2007) and are likely to experience more pressure from stakeholders, consumers, and government bodies (both local and not) (Cowen, Ferreri, \& Parker, 1987). These considerations may therefore explain the attention given to a fuller disclosure of the indicators, both core and additional. Considering both the overall analysis of indicators reported, and the frequency of use of different types of standard indicators, we observe that the most reported indicators in the various sectors are: $\mathrm{ECl}$ (core), which provides information on the economic value generated and distributed, EN3 (Direct energy consumption by primary source Energy) and EN8 (Total water withdrawal by source), again both core. As regards the social dimension, LA1 (pertaining to the main characteristics of total workforce), LA7 (pertaining to the rates of injury, occupational diseases, lost days etc.) and LA10 (pertaining to the average hours of training). These results are consistent with those found in similar studies applied in other areas (Gallego, 2006; Roca \& Searcy, 2012). The absolute importance of the EC1, EN3 and LA1 indicators also emerged from the sample of Spanish companies (Gallego, 2006) and Canadian companies (Roca \& Searcy, 2012).

The same seems to apply to the data used in the construction of many indicators of economic performance, largely recovered from the management and financial accounting system and/or by other company structures (finance, accounting, personnel management, etc.). The construction of environmental indicators can be rather more problematic especially if the company does not have an adequate system for measuring and monitoring the environmental impacts of business activities. In fact, while some data can be obtained from invoices or delivery notes (e.g. data for the construction of EN3) or from water metres or bills (e.g. for the construction of EN8), for other indicators data may have to be obtained from ecological accounting systems or life cycle assessment, etc. (e.g. EN7, EN9, EN12 etc.) which are not always available in companies. The analysis of indicators for each sector shows differences in the disclosure of the various indicators of companies. This result is also confirmed by other studies that highlight that the sector to which a company belongs influences the level of their social, environmental and sustainability disclosure (Roberts, 1992; Tilt, 1994; da Silva Monteiro \& Aibar-Guzmán, 2010; Legendre \& Coderre, 2013; Kansal, Joshi, \& Batra, 2014). The significant disclosure of GRI indicators highlighted by our analysis of sustainability reports can thus be considered positively. As noted, the ruling by GRI of a set of indicators related to a three-year period and defined, with reference to the core indicators, through GRI multistakeholder processes, can be a useful support tool to decision-making processes and to accountability reports. However, if you observe the construction model of indicators proposed by the GRI, you can understand that the cognitive-informative potential of indicators is limited by the absence of integrated, cross-cutting and systemic indicators, both in the third and in the fourth generation of the GRI guidelines. Sustainability reports are unable to propose a structured system of indicators, but as Moneva et al. (2006, p. 134) observe, a «[...] collection of (non-integrated) indicators» unable to support «an integrated and systemic view of business and the environment». Buhr, Gray and Milne (2014, p. 63) state that «[...] the GRI has not managed to gain agreement on a full set of indicators which together might constitute something approaching a social and/or 
environmental accountability». Improving the system of indicators is certainly possible (for example by building an advanced business information system and by extending the stakeholder engagement process) and is auspicious. It is believed that the establishment of a system of indicators that are not only representative of the three dimensions of sustainability but also properly integrated and comparable over time and space and then based on uniform criteria and objective, i.e. independent from the observer, as well as demonstrable and built on topics considered material and understandable by stakeholders, can provide real added value to the assessment of socio-environmental activities of companies.

We have already seen that the disclosure of economic, environmental, and social indicators in a company's sustainability report has been the object of interest of a small number of scientific papers. Our paper, therefore, aims to contribute to the awareness of the use of indicators in sustainability reports produced by Italian listed companies. The results only refer to the sample of listed companies that produce a GRI-based sustainability report and cannot be extended to the wide spectrum of non-listed Italian companies that frequently produce CSR reports. There are several possible lines of development of this research. We might think of enriching the research by analysing not only the indicators in sustainability reports but also the indicators that Italian companies must disclose, in compliance with the provisions of art. 2428 of the Civil Code, in their management reports. Moreover, the recent development of Integrated Reporting highlights the need to overcome the separation between information reported in various statements and in their supplements, in order to achieve an integrated reporting system. In this perspective, the presentation of a system of performance indicators, which summarize the total performance of a company, could offer a concise overall look at the company's system that would be useful in collecting data and information considered material by various stakeholders. The extension of the analysis, within a comparative framework, to other countries would be no less interesting.

\section{References}

AccountAbility. (2008). AA1000 Accountability Principles Standard. Retrieved from http://www.accountability.org/standards/aa1000aps.html

Adams, C. A., \& Frost, G. R. (2008). Integrating sustainability reporting into management practices. Accounting Forum, 32(4), 288-302. http://dx.doi.org/10.1016/j.accfor.2008.05.002

Alazzani, A., \& Wan-Hussin, W. N. (2013). Global Reporting Initiative's environmental reporting: A study of oil and gas companies. Ecological Indicators, 32, 19-24. http://dx.doi.org/10.1016/j.ecolind.2013.02.019

Asif, M., Searcy, C., dos Santos P., \& Kensah, D. (2013). A Review of Dutch Corporate Sustainable Development Reports. Corporate Social Responsibility and Environmental Management, 20(6), 321-339. http://dx.doi.org/10.1002/csr.1284

Azzone, G., \& Dubini, M. (1993). Indicatori per la misura delle prestazioni ambientali. Rapporto 92/04, Milano, Italia: Istituto per l'Ambiente.

Boiral, O. (2013). Sustainability reports as simulacra? A counter-account of A and A+ GRI reports. Accounting, Auditing \& Accountability Journal, 26(7), 1036-1071. http://dx.doi.org/10.1108/AAAJ-04-2012-00998

Brown, H. S., de Jong, M., \& Levy, D. L. (2009). Building institutions based on information disclosure: lessons from GRI's sustainability reporting. Journal of Cleaner Production, 17(6), 571-580. http://dx.doi.org/10.1016/j.jclepro.2008.12.009

Buhr, N., Gray, R., \& Milne, M. J. (2014). Histories, rationales, voluntary standards and future prospects for sustainability reporting. CSR, GRI, IIRC and beyond. In J. Bebbington, J. Unerman, \& B. O’Dwyer (Eds.), Sustainability Accounting and Accountability (pp. 51-71). London, UK: Routledge.

Cho, C. H., \& Patten, D. M. (2007). The role of environmental disclosures as tools of legitimacy: a research note. Accounting, Organizations and Society, 32(7-8), 639-647. http://dx.doi.org/10.1016/j.aos.2006.09.009

Clarkson, P. M., Li, Y., Richardson, D. G., \& Vasvari, F. P. (2008). Revisiting the relation between environmental performance and environmental disclosure: an empirical analysis. Accounting, Organizations and Society, 33(4-5), 303-327. http://dx.doi.org/10.1016/j.aos.2007.05.003

Corporateregister.com, 2013, CR Perspectives 2013, November. http://www.corporateregister.com/downloads/files.html

Cowen, S. S., Ferreri, L. B., \& Parker, L. D. (1987). The impact of corporate characteristics on social responsibility disclosure: a typology and frequency-based analysis. Accounting, Organisations and Society, 12(2), 111-122. http://dx.doi.org/10.1016/0361-3682(87)90001-8

da Silva Monteiro, S. M., \& Aibar-Guzman, B. (2010). Determinants of Environmental Disclosure in the Annual Reports of Large Companies Operating in Portugal. Corporate Social Responsibility and Environmental Management, 17, 185-204. http://dx.doi.org/10.1002/csr.197 
Daub, C. H. (2007). Assessing the quality of sustainability reporting: an alternative methodological approach. Journal of Cleaner Production, 15(1), 75-85. http://dx.doi.org/10.1016/j.jclepro.2005.08.013

Elkington, J. (1997). Cannibals with forks: the triple bottom line of 21 st century business. Oxford: Capstone.

Gallego, I. (2006). The Use of Economic, Social and Environmental Indicators as a Measure of Sustainable Development in Spain. Corporate Social Responsibility and Environmental Management, 13(2), 78-97. http://dx.doi.org/ 10.1002/csr.94

Gallego-Àlvarez, I. (2012). Indicators for Sustainable Development: Relationship between Indicators Related to Climate Change and Explanatory Factors. Sustainable Development, 20(4), 276-292. http://dx.doi.org/10.1002/sd.483

GBS (Gruppo di Studio per il Bilancio Sociale). (2013). Il Bilancio Sociale GBS 2013, Standard, Principi di redazione del bilancio sociale. Milano, Italy: Giuffré.

Gray, R., \& Milne, M. J. (2002). Sustainability reporting: Who's kidding whom?. Chartered Accountants Journal of New Zealand, 81(6), 66-70.

GRI (Global Reporting Initiative). (2000). Sustainability Reporting Guidelines on Economic, Environmental, and Social Performance. June. Retrieved from http://www.epeat.net/documents/EPEATreferences/GRIguidelines.pdf

GRI (Global Reporting Initiative). (2002), (2006), (2011), (2013), (2014). Sustainability Reporting Guidelines. Retrieved from https://www.globalreporting.org/Pages/default.aspx

GRI (Global Reporting Initiative). (2014). Frequently Asked Questions. June. Retrieved from https://www.globalreporting.org/resourcelibrary/G4-FAQ.pdf

Guthrie, J., \& Farneti, F. (2008). GRI Sustainability Reporting by Australian Public Sector Organizations. Public Money \& Management, 28(6), 361-366. http://dx.doi.org/10.1111/j.1467-9302.2008.00670.x

Ilinitch, A.Y., Soderstrom, N. S., \& Thomas, T. E. (1998). Measuring corporate environmental performance. Journal of Accounting and Public Policy, 17, 383-408. http://dx.doi.org/10.1016/S0278-4254(98)10012-1

Jasch, C. (2000). Environmental performance evaluation and indicators. Journal of Cleaner Production, 8(1), 79-88. http://dx.doi.org/10.1016/S0959-6526(99)00235-8

Jasch, C. (2009). Environmental and material Flow Cost Accounting. UK: Springer.

Kansal, M., Joshi, M., \& Batra, G. S. (2014). Determinants of corporate social responsibility disclosures: Evidence from India. Advances in Accounting, 30(1), 217-229. http://dx.doi.org/doi:10.1016/j.adiac.2014.03.009

KPMG. (2008), (2011), (2013). KPMG Survey of Corporate Responsibility Reporting. Retrieved from http://www.kpmg.com/global/en/issuesandinsights/articlespublications/corporate-responsibility/pages/defau lt.aspx

Krippendorff, K. (2004). Content analysis. An introduction to its methodology. London, UK: SAGE.

Legendre, S., \& Coderre, F. (2013). Determinants of GRI G3 Application Levels: The Case of the Fortune Global 500. Corporate Social Responsibility and Environmental Management, 20(3), 182-192. http://dx.doi.org/10.1002/csr.1285

Marston, C. L., \& Shrives, P. J. (1991). The use of disclosure indices in accounting research: a review article. British Accounting Review, 23(3), 195-210. http://dx.doi.org/10.1016/0890-8389(91)90080-L

Milne, M. J., \& Gray, R. (2013). W(h)iter Ecology? The triple bottom Line, the Global Reporting Initiative, and corporate sustainability reporting. Journal of Business Ethics, 118(1), 13-29. http://dx.doi.org/10.1007/s10551-012-1543-8

Mio, C. (2001). Il Budget Ambientale. Programmazione e controllo della variabile ambientale. Milano, Italy: Egea.

Mio, C. (2005). Corporate Social Responsibility e sistema di controllo verso l'integrazione. Milano, Italy: Franco Angeli.

Mio, C. (2010). Corporate social reporting in Italian multi-utility companies: An empirical analysis. Corporate Social Responsibility and Environmental Management, 17(5), 247-271. http://dx.doi.org/10.1002/csr.213

Moneva, J. M., Archel, P., \& Correa, C. (2006). GRI and the camouflaging of corporate unsustainability. Accounting Forum, 30(2), 121-137. http://dx.doi.org/10.1016/j.accfor.2006.02.001

Morhardt, J. E., Baird, S., \& Freeman, K. (2002). Scoring corporate environmental and sustainability reports using GRI 2000, ISO 14031 and other criteria. Corporate Social Responsibility and Environmental Management, 9(4), 215-233. http://dx.doi.org/10.1002/csr.26 
Olsthoorn, X., Tyteca, D., Wagner, M., \& Wehrmeyer, W. (2001). Environmental indicators for business: A review of the literature and standardization methods. Journal of Cleaner Production, 9(5), 453-463. http://dx.doi.org/10.1016/S0959-6526(01)00005-1

Patten, D. M. (2002). The relation between environmental performance and environmental disclosure: a research $\begin{array}{lllll}\text { note. Accounting } \quad \text { Organizations } & \text { Society, } & \text { 27(8), }\end{array}$ http://dx.doi.org/10.1016/S0361-3682(02)00028-4

Perrini, F., \& Tencati, A. (2006). Sustainability and stakeholder management: the need for new corporate performance evaluation and reporting systems. Business Strategy and the Environment, 15(5), 296-308. http://dx.doi.org/ 10.1002/bse.538

Roberts, R. W. (1992). Determinants of Corporate social responsibility disclosure: An application of stakeholder Theory. Accounting, Organizations and Society, $595-612$. http://dx.doi.org/10.1016/0361-3682(92)90015-K

Roca, L. C., \& Searcy, C. (2012). An analysis of indicators disclosed in corporate sustainability reports. Journal of Cleaner Production, 20(1), 103-118. http://dx.doi.org/10.1016/j.jclepro.2011.08.002

Romolini, A., Fissi, S., \& Gori, E. (2014). Scoring CSR Reporting in Listed Companies - Evidence from Italian Best Practices. Corporate Social Responsibility and Environmental Management, $21(2), 65-81$. http://dx.doi.org/10.1002/csr.1299

Samuel, V. B., Agamuthu, P., \& Hashim, M. A. (2013). Indicators for assessment of sustainable production: A case study of the petrochemical industry in Malaysia. Ecological Indicators, 24, $392-402$. http://dx.doi.org/10.1016/j.ecolind.2012.07.017

Schaltegger, S., \& Burritt, R. (2000). Contemporary Environmental Accounting. UK: Greenleaf Publishing Limited.

Skouloudis, A., \& Evangelinos, K. (2009). Sustainability Reporting in Greece: Are we there yet?. Environmental Quality Management, 19(1), 43-60. http://dx.doi.org/10.1002/tqem.20235

Skouloudis, A., Evangelinos, K., \& Kourmousis, F. (2010). Assessing non-financial reports according to the Global Reporting Initiative guidelines: evidence from Greece. Journal of Cleaner Production, 18(5), 426-438. http://dx.doi.org/10.1016/j.jclepro.2009.11.015

Tilt, C. A. (1994). The influence of external pressure groups on corporate social disclosure: some empirical evidence. Accounting, Auditing \& Accountability Journal, $7(4), \quad 47-72$. http://dx.doi.org/10.1108/09513579410069849

Wilburn, K., \& Wilburn, R. (2013). Using Global Reporting Initiative indicators for CSR programs. Journal of Global Responsibility, 4(1), 62-75. http://dx.doi.org/10.1108/20412561311324078

\section{Notes}

Note 1. The G3 and G3.1 guidelines require that the indicators of Sector Supplements be considered core indicators. With the adoption of the G4 guidelines there was also a comprehensive redevelopment of the Sector Supplements, identifying them as GRI Sector Disclosures.

Note 2. In the GRI G3 and G3.1 guidelines, the total number of performance indicators is different. This means that the companies that have adopted different versions of the GRI guidelines, can employ a different total number of indicators. We did not consider this difference relevant, since the decision to adopt one or other version of the GRI guidelines was obviously already indicative of a different behaviour of disclosure. During the analysis, however, we will highlight the indicators present only in G3.1 guidelines, to better contextualize the result.

\section{Copyrights}

Copyright for this article is retained by the author(s), with first publication rights granted to the journal.

This is an open-access article distributed under the terms and conditions of the Creative Commons Attribution license (http://creativecommons.org/licenses/by/3.0/). 